\title{
Compressive Myelopathy Secondary to Multiple Extramedullary Intradural Plexiform Neurofibromas - A Case Report
}

\author{
Siddarth S Joshi
}

\section{Introduction:}

NF1 is the most frequently-observed phakomatosis, with a frequency of occurrence of approximately 1 in 3300. Half of the cases occur via autosomal dominant inheritance, and the rest occur as a result of spontaneous mutations. The NF1 gene is located on chromosome 17 and encodes a protein called neurofibromin, which functions as a tumor suppressor ${ }^{7,9,15}$. Tumoral formations observed in NF1 occur due to mutations in this gene ${ }^{31}$. Despite advances in molecular genetics, diagnosis of NF1 still depends on clinical criteria. The diagnostic criteria were established at the National Institutes of Health (NIH) Consensus Development Conference in $1987^{17}$. The present paper examines the diagnosis of Compressive Myelopathy secondary to multiple extramedullary intradural plexiform neurofibromas with basal ganglia glioma in a 6yearold male patient diagnosed with NF1.

\section{Case Report:}

A 6 year old male child born to a mother with neurofibromatosis, presented to us with history of a cystic swelling measuring $3 \times 3 \mathrm{cms}$ in the left lower aspect of the neck above the clavicle which was insidious in onset, gradually increasing in size since two and half years of age, associated with radicular nerve root pain radiating to the outer aspect of the left hand up to the elbow, which use to increase in intensity on lifting hand above shoulders and lifting heavy objects. As the size of the swelling increased child started developing weakness of the left upper limb, bilateral lower limbs with difficulty in walking. On examination, left upper limb was adducted, flexed at elbow, semipronated forearm, flexed at wrist, extended at metacarpophalyngeal joint and flexed at distal inter phalyngeal joint, with diffuse symmetrical wasting including asymmetrical wasting of left thenar and hypothenar muscles, multiple significant Café au lait spots, with upper motor neuron lesion signs below C6 segment and lower motor neuron lesion signs at the level of C5-C6 segments and with decreased pain sensations involving lumbosacral nerve segments. MRI Brain and Spinal cord was taken in view of the above findings, which showed intradural extramedullary lesion from C2-C5 level with multilevel neural foramina widening, bilateral multiple lobulated lesions in the neck, lumbar and sacral extradural lesions and showing $\mathrm{T} 2 \mathrm{~W}$ hyperintensity lesion in the left basal ganglia, most probably representing multiple plexiform neurofibroma with left basal ganglia glial proliferation. In view of the above findings child was diagnosed to have spastic quadriparesis due to Compressive myelopathy secondary to multiple extramedullary intradural dumbel shaped plexiform neurofibroma.

\section{Discussion:}

NF1 was defined for the first time by Freidrich von Recklinghausen in 1882. A majority (71\%) of the cases has a family history, and the frequency of occurrence is reported to be 1 in 3300 . The NF1 gene is found on chromosome 17 and encodes a protein called neurofibromin, which is a tumor suppressor. Mutations in this gene can result in decreases of this protein by different amounts, leading to development of different types of NF and to the various tumoral lesions seen in NF. Watson syndrome, NF-Noonan syndrome and segmental NF1 are accepted as NF1 variants $8,9,25,31$

Despite advancements in molecular genetics, diagnosis in NF1 depends on clinical criteria. 'Café au lait' spots are seen in $95 \%$ of patients, and axillary and inguinal freckling is observed in $70 \%$ of adult patients with NF1. Both types of spots were detected in our patient as well. They may occur either before or after birth 9,21

The Lisch nodule, or melanocystic hamartoma in the iris, in the most frequently seen ophthalmologic feature in NF and is observed in $95 \%$ of cases. Nevertheless, it was not detected in our patient. In the slit lamp examination, these nodules appear as small, yellowish-brown dome-like lesions located superficially on the iris. Another optic feature seen in NF is optic glioma, which is an optic nerve pilocytic astrocytoma located in the prechiasmatic area. Observed in $15 \%$ of NF patients, it was not detectable in our patient. Though most gliomas are asymptomatic, they may cause visual field defects, diplopia, and ptosis. These two eye conditions are among the important diagnostic criteria for $\mathrm{NF}^{3,19}$

Cognitive disorders can also be observed in NF, including communication disorders (50\% of cases), learning disorders (25\%), and mental retardation (8.4\%). Hyperdense lesions with significant borders on T2- 
weighted MRI, called 'NF1 bright objects', are thought to be responsible for these disorders. These lesions, most of which disappear during puberty, have been reported in 43\%-93\% of patient MRI series, including in the cerebellum, pons, internal capsule, basal ganglia, and white matter. In the case of our patient ${ }^{23,26}$ types, such as head asymmetry, parieto-occipital defects, sphenoid wing aplasia, sella distortion, and expansions of the ipsilateral orbita. The short stature of our patient is consistent with the GH deficiency and early puberty related to NF. The macroglossia, macrocephalia, and specific mandibular anomalies detected in our patient were also related to $\mathrm{NF}^{9,15,25}$.

Vertebral bone anomalies develop independently of spinal and paraspinal neurofibromas. The scoliosis detected in our patient is the most frequently seen skeleton deformity, often observed in the cervicothoracic junction. Its rapid progression may lead to neurological deficits. Moreover, scalloping of the dorsal aspect of the vertebral bones, which was detected in our patient and in $10 \%$ of all NF cases, should always evoke the possibility of an NF1 diagnosis ${ }^{5,10}$.

Neurofibromas are one of the major characteristics of NF1. They can develop from the Schwann cells or fibroblasts of any peripheral nerve. More rarely, schwannoma, menengioma, and astrocytoma from other spinal tumors are observed. Single or multiple skin neurofibromas are observed in more than $95 \%$ of cases. Plexiform neurofibromas, occurring in $30 \%$ of cases, are multiple neurofibromas with diffuse neural expansion along the peripheral nerve ${ }^{10,13,23,30}$.

Nodular neurofibromas may occur anywhere on the peripheral nerves. They frequently originate in the dorsal roots and invade the sensorial branches. They have a round and flexible structure with a capsule. Of the paraspinal neurofibromas, $72 \%$ occur in the intradural extramedullar region, whereas $14 \%$ are extradural, $13 \%$ show a dumbbell formation, and $1 \%$ occur in the intramedullary region ${ }^{10,13,14}$. Neurofibromas in the spinal canal are frequently seen to invade the peripheral segment of the nerve by extending out of the intervertebral foramen and developing a dumbbell tumor. In these dumbbell neurofibromas, the extraspinal part is usually larger than the intraspinal ones. Dumbbell formation is important, especially because the part located in the extramedullary canal attaches to the surrounding tissues. Extremely large tumors have lobular structures and may show cystic degeneration. Tumors extending into the chest cavity retroperitoneally, and subcutaneously have been reported. Neurofibromas can arise in any time of life but they are less frequent before puberty. The number of neurofibromas may range from a few to hundreds or even thousands in adults. Although they are observed in any age, the rate of occurrence may change year by year. The largest number of unusual cases of massive NF1 has been reported from Japan in 1992. In these 24 cases of NF1, multiple brain tumors of different histological types (meningioma and neurofibroma) were found to be associated with spinal tumors. All spinal tumors were intradural and extramedullary; and localized on different parts of spinal canal ${ }^{22}$. A study on 53 children with NF1 conducted in 2003 showed the incidence of localized cutaneous neurofibroma and massive soft tissue neurofibroma as $71.4 \%$ and $28.6 \%$ respectively among 7 patients with spinal neurofibroma, whereas these figures were $39.1 \%$ and $8.7 \%$ respectively in 46 patients without spinal neurofibroma ${ }^{11}$. An article published in 1999 has described a neurofibroma originating from the brachial plexus that involved the right hemithorax, base of skull, spinal cord and cervical vertebra and the importance of multidisciplinary approach for surgical treatment was stressed ${ }^{18}$. The natural progress of 7 children with NF1 from Canada and their treatment alternatives have been reviewed in 2007. Biopsy was performed in two patients, medical treatment was employed in 2 patients (farnesyl transferase inhibitor, R11577 and cyclophosphamide chemotherapy) and surgical debulking was preferred in 3 patients due to the enormous size of tumor. One patient died due to progressive expansion of tumor causing respiratory distress. As a result, the preferred treatment method for these complex lesions has not been clearly defined, but a conservative approach (neuroradiological and clinical follow-up) is recommended in slowly growing lesions whereas surgical treatment may be needed in selected cases that suffer from loss of function due to compression of an organ ${ }^{24}$. Unusual localizations for massive neurofibroma such as hard palate or orbita have been reported. Optimal treatment cannot be defined due to differences in the natural progress and surgical treatment is usually delayed ${ }^{1,27}$.

Clinical symptoms develop as a result of local compression of the ventral or motor nerve roots. Root symptoms develop during the early period, while long tract symptoms develop during the late periods. Cervical and lumbar regions are more frequently invaded. Radicular pain and dysesthesia are present in $80 \%$ of NF cases. The motor weakness that we observed in our patient is seen in approximately $10 \%$ of cases ${ }^{4,13,14}$.

Anomalies detected in the direct graphs are suitable for diagnosis in $50 \%$ of cases. The most frequently reported findings in direct graphs are pedicule erosion and scalloping in the vertebra body. Regular expansion of the interpedicular distance and the intervertebral foramen may directly indicate the presence of the dumbbell tumor ${ }^{4,10,30}$. The specificity and sensitivity of MRI make it quite valuable for detecting the extent of NF and any accompanying pathologies, and for following the development of complications. Neurofibromas give iso- or hyperintense images of the spinal cord in $\mathrm{T} 1$ sequences, while they give hyperintense images in $\mathrm{T} 2$ sequences. Dumbbell neurofibromas enhance the contrast regularly as soon as gadolinium is administered. The complete neural axis should be scanned with contrast MRI in order to detect asymptomatic tumors as well ${ }^{13,26,30}$. 


\section{References:}

[1]. Baden E, Fischer RJ: Multiple neurofibromatosis and neurofibroma of the palate: report of a case. Oral Surg Oral Med Oral Pathol 16: 1356-1364, 1963

[2]. Bhatia S, Khosla A, Dhir R, Bhatia R, Banerji AK: Giant lumbosacral nerve sheath tumors. Surg Neurol 37: 118-122, 1992

[3]. Broniscer A, Gajjar A, Bhargava R, Langston JW, Heideman R, Joner D, Kun LE, Taylor J: Brain stem involvement in children

[4]. with neurofibromatosis type 1: Role of magnetic resonance imaging and spectroscopy in the distinction from pontine diffuse glioma; Neurosurgery 40: 331-338, 1997

[5]. Canbaz B, Tanriverdi T: Norofibromatozis. Aksoy K, Palaoglu S, Pamir N and Tuncer R (eds), Temel Norosirurji, Ankara; 2005: 823-829

[6]. Chapparo MJ, Young RF, Moyra S, Shen V, Choi BH: Multiple spinal meningiomas: A case of 47 distinct lesions in the absence of neurofibromatosis or identified chromosomal abnormality ; Neurosurgery 32: 298-302, 1993

[7]. Guillamoj S, Creange A, Kalifa C, Gril J, Rodriquez D, Doz F, Barbarot S, Zerah M, Sanson M, BastujiGarin S, Wolkenstein P: Prognostic factors of CNS tumours in neurofibromatosis 1 (NF 1): A retrospective study of 104 patients; Brain 126: 152- 160, 2003

[8]. Gutmann DH, Aylsworth A, Carey JC, Korf B, Marks J, Pyeritz RE, Rubinstein A, Viskochil D: The diagnostic evaluation and multidisciplinary management of nerofibromatosis 1 and neurofibromatosis 2 . JAMA 278: 51-57, 1997

[9]. Gutmann DH: The neurofibromatoses : when less is more;Human Molecular Genetics 10(7): 152-160, 2001

[10]. Hirsch NP, Murphy A, Radcliffe JJ. Neurofibromatosis: Clinical presentations and anaesthetic implications. Br J Anaesth 86: 555-564, 2001

[11]. Keles E, Ozer AF: Intrameduller ve ekstrameduller omurilik tumorleri. Zileli M, Ozer AF (eds), Omurilik ve Omurga Cerrahisi, Izmir: 2002: 1113-1119

[12]. Khong PL, Goh WH, Wong VC, Fung CW, Ooi GC: MR imaging of spinal tumors in children with neurofibromatosis 1. AJR Am J Roentgenol 180: 413-417, 2003

[13]. Kloos RT, Rufini V, Gross MD, Shapiro B. Bone scans in Neurofibromatosis: Neurofibroma, plexiform neurofibroma and neurofibrosarcoma. J Nucl Med 37: 1778-1783, 1996

[14]. Lee M, Rezai AR, Freed D, Epstein FJ: Intramedullary spinal cord tumours in neurofibromatosis: Neurosurgery 38: 32-37, 1996

[15]. Levy WJ Jr, Latchaw J, Hahn JF: Spinal neurofibromas: a report of 66 cases and a comparison with meningiomas. Neurosurgery 18: 331-334, 1986

[16]. Levy P, Vidaud D, Leroy K, et al: Molecular profiling of malignant peripheral nerve sheath tumors associated with neurofibromatosis type 1, based on large-scale real-time PTPCR. Mol Cancer 3: 20-33, 2004

[17]. Nakasu S, Nakasu Y, Matsuda I, Handa J: Giant neurofibroma of the scalp associated with lambda defect: case report. No To Shinkei 33: 181-185, 1981

[18]. National Institute of Health Concensus Development Conference: Neurofibromatosis Conference Statement. Arch Neurol 45: 579-588, 1988

[19]. Oliver DW, Wells FC, Lamberty BG, Waters A: Massive plexiform neurofibroma of the sympathetic trunk. Eur J Cardiothorac Surg 16: 569-572, 1999

[20]. Petronio J, Edwards MS, Prados M, Freyberger S, Rabbitt J, Silver P, Levin VA: Management of chiasmal and hypothalamic gliomas of infancy and childhood with chemotherapy; J Neurosurg 74: 701708, 1991

[21]. Pratap A, Negal P, Agrawal A, Singh MP, Pandey SR: Giant malignant nerve sheath tumor of lumbosacral plexus with intraspinal extension in child neurofibromatosis type 1. Pediatr Neurosurg 43: 410-413, 2007

[22]. Riccardi VM: Neurofibromatosis: Phenotype, Natural History,and pathogenesis, 2nd ed. Baltimore: John Hopkins University Pres, 1992

[23]. Sakaida H, Hanakita J, Suwa H, Nagayasu S, Nishi S, Ohta F: Two cases of von Recklinghausen's disease with multiple brain and spinal tumors. No Shinkei Geka 20: 51-56, 1992

[24]. Saltik S, Donmezer B, Yuksel E, Cakı S, Erguven M: Norofibromatozis tip 1 hastalarında klinik ve kraniyal manyetik rezonans goruntuleme ozellikleri. Turk Pediatri Arsivi 40: 94-101, 2005

[25]. Serletis D, Parkin P, Bouffet E, Shroff M, Drake JM, Rutka JT: Massive plexiform neurofibromas in childhood: natural history and management issues. J Neurosurg 106: 363-367, 2007

[26]. Sampson JH, Martuza RL: Neurofibromatosis and other phakomatoses, in Wilkins RH and Rengachary SS (eds), Neurosurgery, volume IB, second edition, Mc-Graw-Hill, 1996: 673-685 
[27]. Shu HH, Mirowitz SA, Wippold II FJ. Neurofibromatosis: MRimaging findings involving the head and spine. AJR Am J Roentgenol 160: 159-164, 1993

[28]. Tada M, Sawamura Y, Ishii N, Chin S, Abe H: Massiveplexiform neurofibroma in the orbit in a child with von Recklinghausen's disease. Childs Nerv Syst 14: 210-212, 1998

[29]. Takayima Y, Friedlander RM, Brem H, Malick A, Martuza RL: Inhibition of angiogenesis and growth of human nevre-seath tumors by AGM-1470. J Neurosurg 78: 470-476, 1993

[30]. Topsakal C, Erol FS, Ozercan I, Murat A, Gurates B: Presacral solitary giant neurofibroma without neurofibromatosis type 1 presenting as pelvic mass: case report. Neurol Med Chir 41: 620-625, 2001

[31]. Unal F: Spinal intradural ekstrameduller tumorler. Aksoy K, Palaoglu S, Pamir N and Tuncer R (eds), Temel Norosirurji, Ankara: 2005; 1121-1128

[32]. Van Es S, North KN, McHuah K, De Silva M: MRI findings in children with neurofibromatosis type 1: a prospective study. Pediatr Radiol 26: 478-487, 1996

[33]. Webb WR, Goodman PC: Fibrosing alveolitis in patients with neurofibromatosis. Radiology 122: 289293, 1977 33. Wise JB, Cryer JE, Belasco JB, Jacobs I, Elden L: Management of head and neck plexiform neurofibromas in pediatric patients with neurofibromatosis type 1. Arch Otolaryngol Head Neck Surg 131: 712-718, 2005

[34]. Woodruff JM. Pathology of tumors of the peripheral nerve sheath in type 1 neurofibromatosis. Am J Med Genet 89: 23-30, 1999 